\title{
LA MIRADA SEDUCIDA (Formas de la rememoración en un relato de Mora)*
}

\author{
María Amoretti Hurtado
}

\begin{abstract}
RESUMEN
Con el pretexto de analizar una de las más enjundiosas novelas del escritor costarricense V.A. Mora Rodríguez, este artículo hace un recuento de las aportaciones teóricas más relevantes en la construcción de la identidad y su relación con la narración, la escritura y el acto estético.
\end{abstract}

\begin{abstract}
With the pretext of analyzing one of the most vigorous novels of the Costa Rican writer V.A. Mora Rodríguez, this article makes a recount of the most relevant theoretic contributions in the construction of identity and its relation with the narration, the writing and the esthetic act.
\end{abstract}

Como ya lo hemos afirmado en otras ocasiones, las obras de Mora presentan una cierta serialidad que las hace constituir un proyecto literario muy uniforme. Podríamos afirmar que la historia que cuentan es en realidad la de la constitución de la subjetividad; se trata de la saga de un yo que busca su propia medida, fuera de toda convención. Su obra completa esboza una cierta lógica interna muy curiosa; digna, por eso, de un acucioso análisis, dada la extraña evolución que va haciendo, obligando al autor a encontrar su propio camino, autoengendrando su destino, a través de sus ficciones. Dadas estas especiales características es que hemos traído a nuestro laboratorio hermeneútico la producción de este autor, para observar en ella el último retrato del sujeto nacional, tal y como lo proyecta la literatura costarricense, cien años después de la construcción de la nación.

En este sentido, los interdiscursos básicos de la obra de Mora se emparentan con dos de los más grandes filósofos de este siglo: Bajtín y Foucault. De aquel asoma el principio dialógico y su teoría de la persona humana y de este la experiencia del límite y una cierta fenomenología de la escritura, a través de la cual el ser adquiere su forma. 
En el presente análisis, utilizaremos una caja de herramientas sociocrítica con énfasis en el pensamiento de Bajtín, pero promoviendo interrogantes de naturaleza epistemológica comparativa y de cooperación metodológica en los que examinaremos marginalmente los siguientes instrumentos conceptuales:

a. Identidad, alteridad y otredad (Bajtín, Lacan; pero sobre todo Ricoeur)

b. Cronotopo y género (Bajtín, Cassirer, Genette)

c. Distancia y aspecto (Foucault, Bajtín, Cassirer, Bachelard)

d. Sujeto cultural-sujeto nacional (Bhabha, Cros, Amoretti)

e. Habitus (Bourdieu, Bajtín)

f. Hibridez (Canclini, Bajtín)

De estas nociones, provenientes de campos distintos como la filosofía, la sociología, la lingüística y la antropología, pero que coinciden en la emergencia de un nuevo horizonte disciplinario conocido ahora como "Estudios culturales", iremos adelantando criterios que preparen el camino para:

1. Propiciar un diálogo transdisciplinario en los estudios de identidad, a través del cotejo de los resultados obtenidos en diferentes disciplinas, especialmente en Historia, Filosofía y Psicosociología.

2. Establecer una caracterización tanto de los aspectos metodológicos como de los cuadros epistemológicos dominantes en el estudio de la identidad, que explique las diferencias y las similitudes detectadas en el cotejo, todo ello con miras a una mejor definición de lo que ahora se entiende por "Estudios culturales".

Con una gran perspicacia, afirma Todorov (1981: 145-50) que toda la obra de Bajtín se apoya en una antropología fillosófica que elabora una cierta concepción del hombre y de su humanidad. Esta concepción bajtiniana del hombre se formula a partir de la alteridad. Aunque, en este aspecto, las ideas de Bajtín se hermanan con las de filósofos como Buber o Sartre, y más tarde aún con los aportes del psicoanálisis lacaniano. Lo que es importante destacar es que esa concepción de la persona humana que Bajtín elabora no es un fin en sí mismo, sino el paso previo y necesario para alcanzar su verdadera tarea: una teoría del acto creador. Es precisamente el sentido del acto creador y su relación con el ser la temática genuina de la obra de Mora que abordaremos a continuación: Memorias de un psiquiatra. (El final del comienzo o viceversa).

Este texto, todavía inédito, pero del cual el autor nos ha facilitado varios manuscritos, no saldrá al público sino en el año 2000, según la disposición comunicada por el autor a la Editorial de la Universidad de Costa Rica. La razón de esta decisión, según sus propias palabras, es un asunto personal y familiar.

Esa determinación no nos extraña mucho cuando nos damos cuenta de que Memorias de un psiquiatra es en realidad una ficción autobiográfica que, además, pone al descubierto la clave de todos sus textos anteriores y muy especialmente de Cachaza, La loca Prado, La distancia del último adiós, La Película y Los problemas del gato. 
Entre todos ellos, merece especial atención La distancia del último adiós, un cuentario que -sólo ahora nos enteramos- había adelantado una especie de obertura de lo que en estos momentos se nos presenta como una gran sinfonía: la historia de una vida.

Efectivamente, Memorias de un psiquiatra. (El final del comienzo o viceversa), de ahora en adelante $M P$, se inicia con los dos relatos más programáticos de ese cuentario publicado en 1995: el que le da título al cuentario, "La distancia del último adiós", y otro más titulado "Recordar". En el primero de los cuentos, que ahora aparece como sintagma inaugural de $M P$, se nos presenta, a través de una suerte de elegía amorosa, lo esencial de su aventura en Estados Unidos: el choque cultural, acrecentado por el ambiente californiano de los años sesenta, el aprendizaje del inglés, el examen de incorporación médica, la búsqueda de empleo y estabilidad, la sensación de extrañamiento, las aventuras amorosas, el fracaso de su matrimonio y la separación de sus hijos.

En "Recordar" se nos presenta el regreso a la tierra natal después de catorce años de ausencia y el impacto de un nuevo proceso de extrañamiento.

Con ambos cuentos, que constituyen una especie de puerta de dos hojas para entrar al nuevo universo ficcional, se nos ofrecen las claves desde donde se produce la tensión que genera toda la actividad fabuladora: la huida y el regreso, pero sobre todo la distancia que media entre ambos. Esta distancia debe ser recuperada por el recuerdo, la memoria, la cual se va a retrotraer más allá de esa huida, hacia los rincones de la infancia y la juventud. El motor que genera esta necesidad retrospectiva es la vivencia de la culpa, motivo que se encuentra claramente explicitado en el cuento "La distancia del último adiós"; de ahí que sea este cuento el que ahora abra el nuevo y extenso relato de $M P$ como su capítulo inaugural.

Así, a partir de ese sintagma introductorio y ese motivo, comienzan a enhebrarse todos los textos anteriores de Mora, los cuales no eran sino fragmentos aislados, episodios sueltos, de esta otra obra suya. MP zurce ahora todos esos episodios en una sola secuencia: el tiempo biográfico.

En esta novela, la vida de un hombre aparece ahí desplegada a través de la conciencia de tres edades cuyos puntos de vista se van ofreciendo alternadamente hasta que el tiempo de la historia y el de la narración se llegan a juntar. El niño y el adolescente de Desamparados se unen con el estudiante de medicina en México y este finalmente con el adulto de Nueva York, el médico que escribe desde el atalaya de su presente. En ese momento, el grueso relato de esas vidas, que no son sino las edades en la vida de un mismo individuo, inicia un diálogo final entre la primera persona de la narración del presente con una segunda persona a la que aquella se dirige como su pasado. Con esta estrategia narrativa, el presente de la enunciación, de la conciencia que ha venido narrando, se desprende del presente del enunciado para convertir a aquel en un pretérito, cuya instancia se revela ahora bajo la forma de un tú, un "otro". La idea narrativa es, como suele suceder en este género, construir una identidad unitaria que se presente como el resultado de lo vivido y que, desde la madurez, enjuicie los errores cometidos. Se trata entonces del tiempo biográfico moldeado en un relato confesional, de tipo picaresco, dado los contenidos de las peripecias contadas. Como todo relato picaresco, la historia comienza con el señalamiento del humilde origen del protagonista y de su ascenso a mejor posición y estado, desde donde, como en la cima de un atalaya, otea el camino recorrido para denigrar sus faltas pasadas. El presente de su atalaya se erige como testigo y juez, gracias a que ahora tiene el conocimiento y la experiencia que antaño no poseía. 
Como práctica social y discursiva, la confesión presenta actualmente dos modalidades, tributaria la una de la otra: la confesión cristiana y la práctica psicoanalítica. La tesis de Foucault sobre la identidad hace de esta un producto de una cierta tecnología de la subjetividad en la que el saber disciplinario y el poder se alían para ligar al sujeto a la verdad, mediante la confesión de esta, a la manera del antiguo auto de fe. Uno de los controles claves de esa tecnología es la práctica confesional, a través de la cual se establece una serie de procedimientos regulados para la confesión, especialmente del sexo, tanto en la práctica cristiana como en la psicoanalítica.

La situación pragmática en la que se nos presenta el primer relato titulado "La distancia del último adiós" es precisamente la de la situación clínica psicoanalítica. El narrador dialoga con un "otro" que es el terapeuta:

Mi niñez, doctor, fue muy triste, tan triste que casi ni la recuerdo: un par de viejos que nunca supieron cómo expresar sus sentimientos, nunca un te quiero, un beso, ella un poco punitiva, dominante, él todo lo contrario. De mi niñez lo que mejor recuerdo son los inviernos. Llueve en mi país, en mi aldea, como si el sol se hubiese muerto, semanas enteras, una tras otra como un cortejo fúnebre... (3).

En el segundo fragmento introductorio de esta novela, el narrador regresa a su tierra natal y se encuentra con un amigo de la juventud que lo espera en el aeropuerto y con quien dialoga insistentemente sobre el pasado para evidenciar nuevamente la distancia que lo separa de su presente. De ahí el título del fragmento: "Recordar":

\begin{abstract}
Salud viejo. Salud. Dura que la pasamos en México. Quique vuelve a sonreír pero ahora su sonrisa es tímida, nerviosa, casi un tic con el que me dice, ya no hablés más de estas cosas, ya dejá de joder, ¿quién quiere acordarse de tanta tristeza, todas las privaciones de los compañeros que nunca terminaron, que quedaron atrás derrotados, algunos convertidos en borrachos... de los compañeros que se suicidaron? Ya dejá de joder con eso que llamás la experiencia mexicana y hablemos de otra cosa... (44).
\end{abstract}

En esta confesión privan dos problemas: el de la sexualidad y el de la culpa. Pero la culpa no se genera del problema de la sexualidad, la cual es asumida por el narrador de manera desproblematizada, a pesar de los excesos que él mismo describe. La culpa se genera más bien por la transgresión de otro tipo de valores, los cuales, muy a su pesar, todavía lo ligan a su cultura originaria. Este es el valor de la familia, pero a esto volveremos después.

Por el momento, MP se nos presenta como un relato confesional acicateado por la vivencia de la culpa, pero la narración se va a deslizar de la situación psicoanalítica hacia la confesión íntima elaborada mediante un diálogo interior que se concreta al final a través del recurso de la segunda persona, justo en el momento en que la historia de ese yo sin nombre se va acercando al presente de la enunciación. Así es como, ya al final de su historia, repentinamente aparece el autor para ayudar a su personaje, a quien comienza a fallarle la memoria al acercarse al presente de quien escribe. Entonces el autor realiza un puente entre el pasado del personaje que se ha hecho presente y se confunde con el presente del autor. Este puente es Golda, la mujer amada de la que venía hablando el personaje. Cito:

La relación de Golda y el que escribe, todavía continúa. Polo (llamemos al protagonista de nuestra historia con el nombre que le puso Nola en aquellos días durante los que se mudó, con Sancho y los otros, al apartamento de La Cerrada de Torreón, la vivienda en donde llega 
a su fin lo que aquel llama su experiencia mexicana, la misma que le para los pelos de punta a su amigo Quique y de seguro a Nola), sigue rememorando, tratando de armar la historia de su vida; Polo se debate estos días con la cronología de los hechos: qué fue primero, el huevo o la gallina, el viaje a Acapulco o el viaje a su pueblo... (422).

La escritura entra en escena y este hecho separa ante nuestros ojos discurso e historia y hace de la primera persona que venía narrando una tercera, un otro. Polo es ahora una tercera persona. Golda es la mediación entre ambos, los cuales no son otra cosa que una representación del pasado (Polo) y del presente ("el que escribe") de un mismo individuo. Es la mención de Golda lo que nos permite entender esta transformación. Por medio de ella el autor realiza un gesto mostratorio que genera a una tercera persona (Polo), un otro que siendo él mismo es, sin embargo, distinto. Es gracias a Golda y a las relaciones que mantiene con uno y otro, como es posible comprender que se trata de dos voces instaladas en una misma conciencia. Esas voces están separadas por la distancia temporal, pero comparten un mismo lugar de encuentro y un mismo propósito: la búsqueda de su ser mediante la juntura, el tejido, de los diferentes instantes de la vida personal que permita definir un final... o tal vez un comienzo. Ya lo veremos.

Por efecto de la transfomación mencionada, la voz narradora ahora es otro yo, un yo nuevo que está ubicado al final de la historia, en el presente desde el que escribe y desde donde nos habla en ese presente compartido. Polo está en el pasado, ciertamente, pero, a su vez, está contenido en el presente de "el que escribe" y esto es lo que nos explica la siguiente transformación gramatical del sujeto que el texto genera:

¿Qué sabes de Nola? ¿Qué se hizo? Casi la matas cuando la dejaste. Le tomó tres años recuperarse del bombazo que le diste. Algunos de sus amigos creían que nunca se podría graduar, se enfermó después de que regresaste a tu tierra sin siquiera despedirte de ella... (442).

Polo es el contenido de la conciencia del que escribe y, al estar allí, es parte del presente de la enunciación; de ahí que quien escribe pueda dirigirle la palabra en una segunda persona dentro de ese presente. Esto es una nueva transformación: ahora Polo ya no es una tercera persona sino una segunda y quien habla de aquí en adelante es el autor. La tercera persona no ha sido más que una estrategia para, por medio de un acto discursivo de nominación ("llamemos al protagonista..."), poder efectuar sobre el yo de la enunciación un gesto mostratorio convirtiendo el sujeto de atribución (Polo) en objeto de atribución.

Lo que el texto ha efectuado con estas transformaciones es una oscilación de sus propios límites genéricos. Inicialmente había creado la perfecta ilusión de una narración autobiográfica, una historia de vida contada en primera persona. Con la segunda transformación, el texto pone en evidencia su propio mecanismo al hacer aparecer la instancia de la escitura como un Deus ex machina que se presenta a escena para revelar la ficcionalidad de esa primera persona refiriéndose a ella como a un otro, una tercera persona ("Polo sigue rememorando..."). Pero la inclusión de Golda y su relación con ambos, con "el que escribe" y con el personaje, "el protagonista", oblitera los efectos de esta transformación. En otras palabras, el límite entre ficción y realidad esbozado se vuelve a borrar y entra en crisis. Una nueva transformación intensifica esta crisis al hacer posible un diálogo entre el personaje y el que escribe, aunque la voz de este último no se escuche. Se pasa entonces de la tercera persona a la segunda ("¿Qué sabes de Nola?"). Lo que tenemos en este momento es precisamente lo que Cros ha denominado "el elemento mórfico esencial de todo relato de vida", a saber: la mirada sobre sí (Cros 1995: 88). 
Pero volvamos al inicio de nuestro análisis, al momento en que describíamos el comienzo de la novela como una puerta de dos hojas, constituida por los núcleos sémicos de los dos relatos inaugurales: la "distancia" y el "recordar". En aras de ofrecer una clara orientación a nuestra operación hermenéutica, vamos a partir de la idea de que en esta novela todo el esfuerzo de la escritura se dirige hacia la recuperación del pasado mediante un ejercicio de rememoración exotópico; es decir, mediante un esfuerzo de objetivación de la conciencia y su propio fluir rememorativo. Todo esto habrá de conducirnos hacia unas conclusiones respecto de la forma en que el tiempo se configura en la narración y hacia la forma en que el tiempo es refigurado por la narración; en otras palabras, nuestro propôsito es examinar el tiempo en dos niveles: como tiempo constituido y como tiempo constituyente.

Para ordenar un poco el desarrollo de esa hipótesis, vamos a dividir el proceso analítico en tres partes:

\section{Fenomenología de la rememoración}

2. La rememoración exotópica y su estructura

3. Modos genéricos de la rememoración y su cronotopo

Después de esas tres partes esbozaremos nuestras conclusiones, es decir, el sentido de los mecanismos de producción elegidos por el texto y descritos en esos apartes, pero sobre todo, nos detendremos a elucubrar sobre el tema del tiempo, la problemática esencial en todo relato de vida, pero más particularmente, la problemática esencial de las obras de Mora en las que la cuestión estética se reflexiona a partir de ella.

\section{Fenomenología de la rememoración}

Las obras de Mora representan un acto auténtico de conciencia temporal. En el caso de $M P$, el mismo título nos señala que se trata de la recuperación del pasado y, sin embargo, la temporalidad predominante de la narración es el presente:

Es la mañana de un domingo. Tú estás sentada radiante al pie de aquel árbol de nueces que flanqueaba la entrada del edificio en donde vivías. Quiero que conozcas a mis hijos y cuando te los presento, se te sale la dicha por los ojos y los invitas a sentarse a tu lado y luego recoges nueces del suelo y se las regalas. Ellos no saben qué decir, son muy pequeños, tanto que estoy seguro que ninguno de ellos debe recordar el episodio. Sólo los viste una vez. Luego de que te empecé a querer como nunca había querido... (10).

Ese presente que la estilística llama presente histórico, en esta novela no es más que la experiencia vivencial del pasado llevada a cabo por el presente de la narración. No se trata, pues, en el caso de los textos de Mora, del tiempo abstracto. El esfuerzo narrativo no se dirige hacia la organización de los eventos en el cauce del acaecer objetivo, sino en el cauce del tiempo de la conciencia, de ahí que, como se puede observar en la cita inmediatamente precedente, no se respeta la consecutio temporum, pues el pretérito imperfecto aparece como un correlato temporal del presente, fenómeno que provoca una sincronía, una mirada que presentifica el pasado. 
El tiempo de la conciencia, según Ernest Cassirer "no nos puede ser dado de otro modo que como "tiempo presente"” (1976: 202). Esta afirmación del filósofo alemán se basa en las reflexiones que San Agustín elucubra en sus Confessiones, al afirmar que en rigor no se debería hablar de tres tiempos diferentes, sino de que el tiempo, como presente, involucra tres distintas relaciones. Así:

Nec proprie dicitur. Tempora sunt tria: praeteritum, praesens et futurum; sed fortasse proprie diceretur: tempora sunt tria, praesens de praeteritis, praesens de praesentibus, praesens de futuris. Sunt enim haec in anima tria quaedam et alibi ea non video: praesens de praeteritis memoria, praesens de praesentibus contuitus, praesens de futuris expectatio (Agustinus. Lib. XI, Cap. 26).

En otras palabras, el tiempo de la conciencia es una unidad que sintetiza tres intenciones u orientaciones, claramente señaladas: una dirigida al ahora, otra al antes y otra al después. Es, pues, el presente de la conciencia el que mide el tiempo y lo mide en la impresión producida, la cual es una impresión presente.

Todo lo anterior explica, fenomenológicamente, el porqué lo menos que se respeta en el acto rememorativo de los relatos de Mora es la cronología de los hechos:

\begin{abstract}
Yo, sin ocuparme de la secuencia de los hechos en el tiempo, continuaría con el relato, empezaría este apartado de sus memorias, cuando él está listo para partir hacia Puebla a hacer su servicio social; o en la ciudad de Manhattan cuando se alistaba a viajar hacia su país por la primera vez, después de catorce años de exilio voluntario; o cuando se hallaba en Acapulco, de vacaciones con Golda...

Polo, ¿recuerdas cómo te quería Nola.......? (422).
\end{abstract}

Al encontrarse el relato de la primera persona de Polo con la voz autorial de "el que escribe", se nos anuncia que ya ninguna cronología tiene importancia. Todo lo que ha sido dicho con anterioridad y mediante la escritura es remitido ahora a un orden gobernado por este momento actual. Este origen es el único tiempo posible y el único presente. Es precisamente este momento de encuentro entre esas dos voces en el lugar de una misma conciencia, el que problematiza toda cronología. La memoria de Polo comienza a fallar justamente en ese instante porque ese instante es el momento de la objetivación misma del acto auténtico de conciencia de "el que escribe", instante que nos revela, en consecuencia, cómo la voz que habíamos venido escuchando está contenida dentro del espacio mismo de la conciencia de "el que escribe"; a partir de ese momento, el examen y la evaluación de lo vivido se tramita mediante la estructura dialógica:

\footnotetext{
Polo, ¿recuerdas cómo te quería Nola, cómo te ayudó a prepararte para el servicio social, cómo te regaló muestras médicas para que hicieras negocio vendiéndolas a los indios de la Sierra Norte? (...) Casi la matas cuando la dejaste. Le tomó tres años recuperarse del bombazo que le diste... (422).
}

La jerarquía, el orden de los hechos, están dictados por la intensidad y calidad del contenido que es objeto de la rememoración. Lo que mide la conciencia de "el que escribe", que es el auténtico lugar de la rememoración, no es algo objetivo, sino la impresión que dejan en ella los acontecimientos, los cuales, por esa misma impresión es que permanecen fijos en esa conciencia. En $M P$ el tiempo que se explaya es, paradójicamente, el tiempo del instante, es decir, el instante del acto de conciencia; es este instante el que contiene el peso de toda una 
existencia y se mueve, se vuelve fugitivo. De ahí la confusión cronológica, pues los instantes del ayer y aquellos que apenas se avizoran se funden en un solo momento, el momento de la reflexión que la escritura genera:

\begin{abstract}
Me cuesta escribir nuestra historia, Susana. Imagino que tengo miedo del final, miedo de esperar nuevamente, confundir las llamadas telefónicas en la televisión, con el ring de mi teléfono. Mi teléfono no suena. A veces me parece que suena pero es sólo mi imaginación. Tú no me llamas y yo no hago más que soñar con tu voz, esperarla, esperar que digas, he cambiado de parecer, voy a regresar a tu lado. El teléfono no suena (24).
\end{abstract}

Por las anteriores consideraciones, tal vez lo adecuado para tratar la dimensión temporal en Mora es separar el tiempo pensado del tiempo vivido, de la misma forma en que los griegos separaron siempre el cronos del kairós. Según el autor, la secuencia de hechos no es lo que importa, lo que importa es la relevancia de esos hechos y esa relevancia es decisiva, lo que es literalmente significativo.

Si bien la reflexión del tiempo como kairós es muy antigua (Aristóteles le dedica abundante reflexión, por ejemplo), corresponde a Manfred Kerkhoff (1997), pensador alemán que se desliza de la especialidad de la Filología Clásica hacia la Filosofía después de su encuentro con esta concepción griega del tiempo, el mérito de haber elaborado una teoría filosófica que bien merece el nombre de kairología o kairosofía.

La kairosofía privilegia el tiempo vivido y, dado que es este filósofo el que nos ofrece en la actualidad el aparato de reflexión más acabado dentro de ese campo, nos apoyaremos de aquí en adelante en sus conceptualizaciones.

Según Kerkhoff, el kairós (del griego: tiempo justo, tiempo oportuno) es un instante de decisión y, por ende, un instante extraordinario que marca a la vez un punto inicial o final; de ahí el subtítulo de la novela "El final del comienzo o viceversa". Al enfrentar el tiempo en su cualidad kairológica, la narración se llena de saltos temporales abruptos, de idas y venidas y de sempiternos retornos. El "ahora" del relato, que se repite obsesivamente en $M P$ aparece como un término equidistante entre diferentes espacios y lapsos temporales. De ahí que ese "ahora" que Agustín llama "contuitus" (atención) sea luego interpretado por Heiddeger como una especie de fascinación de la mirada y caracterice el "hacer presente" del pasado en nuestra conciencia como una "mirada seducida". En el caso de $M P$ esa seducción por el pasado se origina en la medida cualitativa del peso de los hechos rememorados. El "ahora" es sinónimo del cambio, de la alteración del curso, porque de eso se trata esta novela, del camino de una vida, pero sobre todo de sus encrucijadas y sus fatales iniciativas.

Según Paul Ricoeur (1996: 974), el verbo que expresa mejor el presente es el verbo "comenzar":

Comenzar es dar a las cosas un curso nuevo, a partir de una iniciativa que anuncia una sucesión y así abre a una nueva duración. Comenzar es comenzar para continuar: una obra debe seguir.

Vienen aquí al caso unas precisiones, por desgracia insuficientemente desarrolladas, hechas por Foucault a propósito de Robbe Grillet. Allí, Foucault afirma que los espacios que la distancia separa no se excluyen en la memoria sino que son un recurso de esta para presentar 
"un ser fuera de sí, consigo, y en ese 'con' donde se cruzan los que están lejos" (Antologado por Gabilondo 1996: 168) y continúa diciendo que ese límite que impone la distancia es:

\begin{abstract}
una línea que no cesa de saltar por encima sin que se borre, como si, por el contrario, fuera cruzándola sin parar como se la marca aún más. Porque ese límite no aísla dos partes del mundo: un sujeto y un objeto, las cosas frente al personaje; es más bien la relación universal, la muda, laboriosa e instantánea relación por la que todo se anuda y se desanuda, por la que todo aparece, centellea y se distingue, por la que en el mismo movimiento las cosas se dan y se escapan (...) Dos espacios que poseen el secreto de estar por completo aquí y allí; de estar donde está la distancia (...) y sin embargo, en la más cercana vecindad (169).
\end{abstract}

De ahí que MP no destaque tanto el tiempo como cronología, sino eso otro que los gramáticos llaman el aspecto. Es este accidente lo que interesa. En él se reúnen las categorías de lo acabado, inacabado, la proximidad, el alejamiento, la continuidad, la iteración. De ahí también la obsesión por los epílogos, la sagitalidad, la deixis que ejecutan unas obras en el conjunto de la producción de Mora. La historia que se repite, la venida, el retorno que instaura un tiempo morfológicamente indeterminado pero aspectualmente siempre en progreso. El concepto de distancia foucauldiano, a diferencia de la noción de espacio, no ofrece las cosas en su sitio, sino en su venida, en el movimiento que las presenta y las hace que pasen. Esta manera de captar las cosas no es una percepción temporal, sino aspectual, con toda la precisión gramatical que este concepto implica en el sentido de una "tensión" temporal. De ahí la pertinencia de la cita de Ricoeur y la relación que establece entre el presente y el verbo "comenzar" y la idea de sucesividad que ambos entrañan. Por otra parte, las palabras de Ricoeur explican nítidamente el sentido de la arquitectura temporal de MP y su conceptualización de la idea del tiempo, como también explicaría el sentido del acabado del relato, su final, y el motor de su generación: la culpa, ya que esta compromete el porvenir. Pero de esto hablaremos en el tercer apartado titulado "Los géneros de la rememoración y sus cronotopos".

En síntesis, en $M P$ el momento axial es el modelo de todo comienzo del tiempo en el tempo subjetivo de la conciencia; por eso podemos afirmar que se trata de una historia de vida que se organiza según la medida kairológica de los eventos de una existencia. Los eventos elegidos son evaluados por su capacidad para indicar otras partes del tiempo que aparecen como la consumación de aquellos. Pero el instante vivido como "lugar" de una posible decisión nos sitúa en una dimensión "vertical" que se distingue de la dimensión "horizontal" del transcurrir como el saltar del correr. Esto explicaría la composición de la novela en ciernes, como se verá en el próximo apartado que hemos titulado "La rememoración exotópica y su estructura".

De modo que lo rememorado en MP son los instantes que, por las anteriores razones, a memoria presentifica como su propia culminación. No son, pues, todos los instantes de una wida, sino tan solo algunos, los instantes de cambio, las encrucijadas. Lo que del no-presente zasado) se presentifica en esa conciencia son los momentos cruciales, dramáticos, los momentos de una toma de decisión, cuya trascendencia se prueba precisamente por el hecho de su actual presencia aún después de que el hecho ya no exista.

Así, en $M P$, el acto rememorativo, en su mismo proceso, valora los instantes de los que se hace cargo como momentos únicos, extraordinarios. Se trata de momentos que se dievan sobre otros y son únicos porque, paradójicamente, lo que ocurre una sola vez reúne zencro de sí la primera y última vez (el viceversa del título). Como el momento único reúne 
dentro de sí el antes vivido y el porvenir, el sentido profundo de este acto de conciencia es el de construir una correlación ideal de las relaciones temporales agustinianas, mediante la cual la vida se da forma a sí misma. De ahí que la significación de este acto auténtico de conciencia temporal tenga como objetivo la búsqueda del ser a través de la cual el yo se asegura su identidad, pero será una identidad narrativa.

\section{La rememoración exotópica y su estructura}

Como ya se dijo, la composición de $M P$ pareciera estar determinada por la alegoría de las edades del hombre, ya que se compone esencialmente del recuerdo de eventos de la infancia, de la adolescencia y de la edad adulta de un hombre. Pero en realidad no es así. Es mera coincidencia que los cortes coincidan con esas edades. El criterio seguido para la estructuración de los acontecimientos es más bien lo que Bajtín llamaría la inserción de ciertos cronotopos, a saber: el viaje, el encuentro, la huida y la separación.

Los eventos de la infancia son los más esporádicos, el grueso del relato se concentra en la entrada a la adolescencia, la juventud de estudiante tanto en el liceo como en la universidad y luego la vida adulta y profesional. El viaje a México constituye el primer corte, todos los acontecimientos anteriores a él no son más que su preparación, la forma cómo en su suceder sobreviene el viaje. El segundo está dado por el encuentro con la mujer que será su esposa y será interrumpido por la separación, la huida y un nuevo viaje. La tercera parte y final la señala entonces otro encuentro, el que tiene con la mujer por la que abandona su hogar y su familia (una nueva huida) y termina con un nuevo encuentro, esta vez consigo mismo, en su regreso a su país natal. De modo que, en cierta forma, el final de la historia no es más que su comienzo, ya que es a partir de ese encuentro consigo mismo que se genera el relato y su decurso. Esta estructura corresponde, a pesar de sus variantes, al tiempo biográfico, a la imagen del hombre que recorre su camino. En consonancia con lo anterior, a la serie temporal se liga, en esta novela, una serie espacial que coincide con la estructuración antes mencionada y que podría esquematizarse de la siguiente manera: Costa Rica-México-Costa Rica-Estados Unidos-Costa Rica. Esta serie espacial, como tampoco la temporal, no es tan simple como su esquematización la presenta, pero esos espacios marcan de alguna manera los instantes extraordinarios de los que hablábamos en el aparte anterior. El viaje a México para estudiar medicina significa el toque de gracia que su madre propicia desde su infancia y que va a significar una determinación importante en su destino vital. Su intempestivo matrimonio al regreso a Costa Rica es otro momento crucial, tan crucial que el narrador se describe a sí mismo como "el hombre al que toda la vida le han resultado las cosas, todas sus empresas, hasta que se casó" (p. 386). Su viaje a los Estados Unidos es tan definitivo que termina convirtiéndolo en un otro problemático que deberá regresar a Costa Rica, después de catorce años de ausencia, para ajustar cuentas consigo mismo y con sus seres queridos. Cada uno de esos momentos extraordinarios significan procesos de transformación o de metamorfosis, de ahí su relevancia. Porque esa coordenada espacial es siempre "otro país", procesos de extrañamiento cultural se van a agregar a los procesos de metamorfosis psicológica que van a complicar todavía más la búsqueda de sí mismo y de su identidad. 
La serie espacial materializa la metáfora del camino vital, cronotopo por excelencia del relato biográfico, porque la serie temporal y la estructura composicional del relato se dan efectivamente gracias a una coordenada espacial cambiante.

Esta dispersión del tiempo en el espacio la recorrió admirablemente el Dante en los versos iniciales de su nunca imponderable Divina comedia: "Nel mezzo del cammin di nostra vita / mi ritrovai per una selva oscura / che la diritta via era smarrita". En ellos, la imagen del "camino" es en realidad el perfecto cronotopo miniatura, es decir, el epítome de la unidad espaciotiempo. Eco lo comenta admirablemente en su libro Los límites de la interpretación. Como es obvio, "vida" contiene una marca de temporalidad mientras que "camino" contiene una marca de espacialidad; pero gracias a la frase adverbial "nel mezzo" en medio de la co-ocurrencia de "camino" y "vida" se da una transferencia de propiedades, de forma tal que "camino" pasa a ser una categoría temporal y vida se entiende como una categoría espacial. Lo anterior es posible ya que ambos lexemas contienen una marca de proceso, de transición de x a y. Así:

decurso en el tiempo vida traslación en el espacio

camino

No vamos a ahondar más en un asunto que no sólo el Dante, sino hasta el mismo Parménides, antes que el Dante, o Manrique, o hasta el mismo Juan Ramón Jiménez han contribuido a la sobrecodificación de esta imagen poética que logra trascender tanto la noción de proceso temporal en vida, como la del proceso de traslación espacial en camino, para vertir en la imagen de la vida como camino, valga decir, como viaje o recorrido, otras propiedades que implican un conocimiento del mundo. Así, los versos ya citados, a través de las nociones de oscuridad o de rectitud, refieren al miedo, a los peligros y a un comportamiento moral. En MP, "Nel mezzo" no es el centro del recorrido vital, sino más bien el final de un camino y el comienzo de otro. La vida biográfica que allí se despliega está tan llena de encrucijadas que se produce un fenómeno exotópico sin precedentes, como se verá más adelante.

Las tres edades aludidas no solo están determinadas por cronotopos, más que por los años, sino que tampoco están acomodadas cronológicamente. Una edad no sucede a la otra, ni dentro de ellas los acontecimientos siguen necesariamente una línea recta.

Las supuestas edades se fragmentan, gracias a esos cronotopos, por los cambios de espacio y se insertan fragmentariamente unas dentro de otras, como en racconto: Nueva York, San José, México, Nueva York, San José, México, Nueva York y así sucesivamente.

La infancia, pobre y triste en San José, aparece alumbrada por "sueños de países lejanos y lugares nuevos..." estimulados por los exilios de algunos tíos y los viajes de su abuela:

La abuela en ese tiempo se ausentaba por meses; su hijo Luis Carlos la invitaba a México. De esos viajes regresaba cargada de regalos y de unos almanaques con imágenes de la campiña y de los volcanes mexicanos. Los regresos de la abuela eran motivo de fiesta; casi toda su familia la esperaba en el aeropuerto. Recuerdo la gran ansiedad con la que yo escrutinaba el horizonte desde la terraza de La Sabana y cómo un minúsculo punto negro que aparecía salido de la nada, poco a poco crecía hasta convertirse en la silueta de un avión con dos motores que con gran estruendo terminaba posándose a pocos pasos de todos nosotros y del que descendía la abuela muy campante llenando mi corazón con sueños de países lejanos, de lugares nuevos... (34-5). 
El cuadro inicial de la infancia, su pueblo y su familia, está enmarcado por la visión del adulto que señala claramente la distancia temporal y espacial:

\begin{abstract}
Ya no visito a mi país con la frecuencia con que lo hacía otrora; mis hijos se hicieron grandes (la mayor está casada y el hijo mayor vive conmigo); mis padres fallecieron y mi hermano sigue siendo un extraño...

En la capital de México no he estado desde que pasé por ahí en 1965, rumbo a este país (...) De los dos lugares lo único que quedan son coordenadas, nombres, memorias; la gente, que es lo más importante -los que sobreviven-, han cambiado... (32).
\end{abstract}

Sobre la base de esta metáfora de la vida como viaje en la que se suman categorías espaciales y temporales, en la obra de Mora el fluir del tiempo se da gracias al recorrido de espacios y a las distancias resultantes de este recorrido. A partir de esa distancia, medida, sin embargo, por el tiempo vivencial y no por la coordenada espacial, la narración se desplaza en tres direcciones diferentes que se van alternando algorítmicamente, de modo que siempre vuelven: Costa Rica (los años de estudiante de secundaria); México (los años de estudiante de medicina); Estados Unidos (los años de soledad, después de la separación de su familia y la pérdida de su gran amor, Susana). efectos:

El devenir de estos fragmentos que se alternan en la narración produce los siguientes

1. Una cierta autonomía de una época respecto de las otras. Se puede hacer el ejercicio de leer esos fragmentos separadamente y encontrarnos que tienen su propia unidad y secuencialidad aunque dentro de ellos se dan otros desplazamientos. En Costa Rica, del pueblo de Desamparados a la Capital; en México, del D.F. a la Sierra Norte; en Estados Unidos, de Saint Louis a California y a Nueva York.

2. La ilusión de sincronía al desplegarse esas épocas en forma simultánea y alternada. Esa ilusión de sincronía es también reforzada por la constante irrupción del presente morfológico y sus deícticos, lo cual hace que una edad ignore a la otra y que el devenir aparezca como ciego. La ilusión del pasado que se vive como presente dentro de cada una de esas épocas hace que los acontecimientos no tengan para ese instante ninguna orientación teleológica. He aquí algunos ejemplos de la presencialidad del pasado que se evidencia por los deícticos y por el uso del presente en los diferentes fragmentos y niveles temporales (los subrayados siguientes son nuestros):

En San José, pasado más remoto:

Aquí estamos desde hace por lo menos una hora, a la espera de que llegue el famoso cantante argentino que se ha ofrecido para entretenernos esta mañana. Los corredores de la segunda planta están abarrotados, las escaleras que conducen a este patio, lo mismo. Hace calor. La luz es tan brillante que si miro al cielo, se me salen las lágrimas. El artista que va a cantar es famoso, canta tangos y se llama Alberto Castillo (287).

En México, pasado intermedio:

Aquí no volví a misa ni a confesarme. Ni siquiera me he parado en la misa que la colonia tica celebra en una iglesia de San Juan de Letrán, el día de la Virgen de los Ángeles. No conozco una sola de las iglesias de la Colonia Roma (285). 
En Estados Unidos, pasado reciente:

Eso fue la semana pasada. Hoy hemos invertido los roles y yo he empezado a confesarme, contándole un apartado doloroso de mi vida que en California usé, con buen éxito, para conseguir lo que parecía imposible por otros medios. Hoy, a mi táctica de la gota de agua, añado la imagen del hombre con inmensos problemas, el hombre errático al que hay que tenerle lástima, compasión, en vista de la enfermedad mental que en ocasiones me aturde (385).

Así, la conciencia crea un sentido histórico produciendo a través de las relaciones temporales agustinianas (presente del pasado, presente del presente y presente del futuro) una totalidad cuyo centro es la propia conciencia del presente. La forma de la fragmentación temporal en $M P$, entrecruzando pasado y futuro, produce el efecto de esta totalidad que es el presente histórico y lo tematiza desplegando contigua y simultáneamente las consecuencias futuras de un acto presente y este como producto de una acción precedente, todo en un mismo plano temporal o sincronía. Por tanto, la fuerza de la refiguración del tiempo en $M P$ proviene del presente y de la contemporaneidad de los procesos de las demás dimensiones temporales (aspecto progresivo). Todo esto es además reforzado por el siguiente rasgo.

3. La intuición de una causalidad implícita, pues a pesar de la segmentación y la heterocronía simultánea, a esos fragmentos los une la visión del adulto quien escribe desde el futuro de la historia narrada.

Efectivamente, el avance cronológico en el interior de esos fragmentos los hará llegar a encontrarse ineluctablemente para constituir la recta horizontal del camino vital. Eso ocurrirá cuando el estudiante de secundaria tome el avión hacia México; el estudiante de medicina regrese a su patria hecho médico para partir, un año después, ya casado, hacia los Estados Unidos y allí se anudarán todas las épocas anteriores. Pero la recta de ese camino vital va a encontrar en ese punto dificultades para acomodar todos los eventos; de ahí la confusión de Polo que ya no sabe, por ejemplo, "qué fue primero, el huevo o la gallina, el viaje a Acapulco o el viaje a su pueblo. Polo se debate en estos días con la cronología de los hechos" (422).

Es en este punto axial donde se produce el fenómeno exotópico. Este es el momento en que Golda, la mujer definitiva, hace converger técnicamente todos los fragmentos, los cuales van a volver inmediatemente a separarse, esta vez en dos: el antes y el después, gracias a la irrupción de la conciencia que rememora estas rememoraciones (la redundancia aquí es no solo consciente, sino también buscada). Mediante el recurso exotópico de la segunda persona, precedido por una tercera persona transicional, el fenómeno del rememorar se pone en acto dejando al descubierto el mecanismo puro del género autobiográfico. Según el insigne estudioso del relato autobiográfico, Philippe Lejeune, la presencia del "yo" en ese género está íntimamente ligada al nombre propio del autor, de modo que esa primera persona está implícitamente escondiendo una tercera. En MP es la figura de Golda la que revela este enmascaramiento haciendo coincidir a ambas existencialmente, pero desplazándolas en una sincronía técnica a través del sistema pronominal. De ahí que hayamos ya afirmado que Golda es un digno mostratorio, como lo es la tercera persona transicional. Hay en esto una develación del pacto autobiográfico cuya sola mostración o exposición denuncia el carácter ficcional de todo sujeto y de toda identidad. Pero del tema 
autobiográfico y su técnica hablaremos en el siguiente apartado. Por el momento, lo que nos interesa es el fenómeno exotópico.

Para que la dialogía se dé es necesaria una segunda persona y esa es la razón por la que esa tercera persona de la que veníamos hablando se transforma seguidamente en una segunda.

¿Qué es la exotopía y cuál es su función? Etimológicamente hablando, el término "exotopía" significa "salida", "encontrarse afuera", abandonar el lugar donde se está. Específicamente hablando, Bajtín la emplea para nominar una "salida de sî", una exteriorización mediante la cual se da una objetivación del sí. Pero obsérvese que esta operación se produce en MP gracias a la previa objetivación temporal. La red de entornos que se da por la alternancia algorítmica de los fragmentos, produce una heterocronía que, a pesar de la independencia de los acontecimientos acaecidos en esos fragmentos, invita a una comprensión del conjunto de fines adivinables y pone en evidencia el punto axial de donde emerge la coincidencia y la conciencia del tiempo. La horizontal de la recta vital es problematizada por la estructuración que reposiciona los eventos de tal forma que cada uno de ellos contiene dentro de sí una indicación hacia otros que se nos representan como su consumación o como su inicio, conteniéndose todos dentro de cada uno de ellos. Como ya lo dijimos, esos eventos son elegidos por su carácter kairológico, por ser momentos decisorios y, por ende, ontomorfos, de modo que la línea recta horizontal del camino de la vida adquiere más bien una configuración de interrupciones temporales que se elevan por su forma de pico, de momento cumbre, estableciendo un eje vertical de valoraciones que genera lo que se puede llamar la medida supratemporal.

Al ser estos instantes punto inicial y final a la vez, se representan como puntos cortantes de dos espacios de tiempo que se definen como antes de ese instante y después de él. Lo anterior hace posible una transición sin ruptura, ya que el instante extraordinario, por su propia trascendencia, se encuentra presente en cada uno de los otros (el antes que él transforma y el después que por ello se produce) y es él el que genera el tiempo interrumpiéndolo para hacerlo objetivable, cognoscible, medible y evaluable; de ahí que Lejeune rectifique, después de su libro La pacte autobiographique (1975), el papel de la cronología en la autobiografía, cediéndole importancia al orden temático en el género.

Pero el centro del proceso, su punto central, no es ninguno de esos espacios ni ninguna de esas temporalidades, sino el yo que imagina la "temporacialidad" y es él quien, al separar los trayectos diversos, los une justamente por emanar de la misma fuente. La conciencia es, pues, la generadora del tiempo y la que lo instancia en imágenes que, en este caso, constituyen unidades también espaciales: por eso hablamos de "temporacialidad". La conciencia es el punto infinito que genera las finitudes en que el relato se estructura buscando una clausura que, sin embargo, no se da, a pesar de presentirse un final. La idea estética está afectada por la noción de acabamiento, que le es inherente, pero en el caso de MP, la idea del relato abierto no sólo es consecuencia del paradigma estético de la época, sino también un efecto del relato de vida; de ahí que el final del texto no sea más que su continuación: "A empezar una nueva vida... a seguir la vida" (500), sólo que en otra tesitura.

Entonces, esta problematización de la recta horizontal del camino convoca, con la ayuda de los procesos de presentificación y la deixis ya aludidos, el momento estático y extático de la toma de conciencia que es ese lugar de donde nace el tiempo a partir de una medida supratemporal que lo convierte en imágenes a la vez que temporales, espaciales. Es allí, en ese otro nivel, en donde se llega, al final de estas operaciones de la imaginación pura, a 
experimentar el experimentar mismo del tiempo y la medida es supratemporal porque si bien ese lugar determina la calidad y cualidad de los eventos, está al mismo tiempo determinado por ellos. Sólo en ese instante en que se experimenta el experimentar mismo del tiempo es posible la exotopía: un espacio desprendido de otro que señala el límite entre un tiempo medido, finito, y otro tiempo, el gran tiempo infinito de la conciencia. Justamente, es Bajtín (Todorov 1981) quien señala que la especificidad de la conciencia es la infinitud. Según el filósofo ruso, los acontecimientos de mi nacimiento y de mi muerte, de mi estar en el mundo, no se realizan en mí ni por mí, sino en el otro. Yo sólo muero para los otros y, por eso, para mí, sólo los otros mueren. "En todos los cementerios, dice Bajtín, los que están son siempre los otros" (Todorov 1981: 151. La traducción es nuestra). No será mera coincidencia que el otro relato que se analizará tenga al cementerio como un centro álgido y su título aluda al tema de la muerte. Todo tiene un comienzo y un fin (la vida, el hombre, el destino) excepto la conciencia, la cual es por naturaleza infinita. Es esta infinitud de la conciencia el leit motiv de las obras de Mora. En ellas, el sujeto hace la experiencia del sí mismo en el instante realmente presente y pleno, pues para él, el sentido de la vida sólo es confirmable en la propia vivencia de este instante en que me sé vivo. Pero para lograr esta experiencia del sí mismo necesito objetivarme en alguien distinto de mí mismo, en un otro yo a través de cuyos ojos pueda efectuar la mirada de mí mismo desde la exterioridad. He aquí el principio de alteridad, como condición previa a toda dialogía.

En el otro bajtiniano no hay paralelismo entre el otro y el sí mismo. Yo y el otro son radicalmente distintos, asimétricos.

El otro es necesario para llevar a cabo la percepción de sí. La imagen que yo veo en el espejo es necesariamente incompleta, pues no es más que el arquetipo de la percepción de sí. Sólo la mirada del otro me puede dar el sentimiento de que yo formo una totalidad. Sólo el otro puede crear esta personalidad exteriormente completa. Nuestra idea de lo que es una persona entera, completa, sólo nos puede venir de la percepción de otros y jamás de la que tenemos nosotros mismos. De esta manera, "el que escribe" en MP le completa a Polo su imagen al indicarle el sentido de sus actos y señalarle sus momentos kairológicos; pero Polo también es el punto de referencia que completa el sentido de la vida de "el que escribe". Ese es el sentido de la puesta en escena de la conciencia dialógica en $M P$, operación que no se debe confundir con un desdoblamiento porque el otro, ese Polo al que se dirige "el que escribe", es un otro muy distinto, no es la alteridad neofreudiana.

El sujeto bajtiniano no es un sujeto especular, es un otro; por eso se comunica aún en su alteridad, mientras que en el sujeto neofreudiano el otro no dialoga, entre ellos lo que se da es un monólogo.

En el discurso especular del neofreudianismo (Lacan) el sujeto se disuelve en su propia imagen en un discurso sin el otro.

La otredad para Bajtín no equivale a la alteridad neofreudiana o psicoanalítica, sino que apunta a las voces opositivas dentro de una cultura, en los enunciados reducidos al silencioy que recobran su voz en el carnaval (este sentido carnavalesco va a emerger en otra novela de Mora, Mano a mano (1988) la cual será una jocosa continuación de MP y su parodia).

La alteridad neofreudiana no debe confundirse con la otredad bajtiniana; la primera se refiere a las dimensiones psicoanalíticas y la última a un otro distinto (another) de uno mismo. Según Derrida, el otro (el alter neofreudiano) es la diferencia en la economía de lo 
mismo. El sujeto bajtiniano se comunica con el otro a pesar de la alteridad, por eso la forma semiótica de la conciencia es el microdiálogo y su forma sociológica son las voces (la polifonía). Para Bajtín, los enunciados, aunque emanen de la reflexión de un hombre solo, son monológicos únicamente en su forma exterior, ya que por su estructura semántica y estilística son esencialmente dialógicos. Todo enunciado se concibe en función de un auditor; así, cuando en $\boldsymbol{M P}$ se interrumpe la rememoración de Polo, se hace evidente la presencia de "el que escribe" como su auditor, el cual a su vez dirige explícitamente a otro auditor que es el lector: "...Polo (llamemos al protagonista de nuestra historia con el nombre que le puso Nora por aquellos días)..."

"El que escribe", como auditor de Polo, comprende y responde a ese discurso. "El que escribe" expone su percepción evaluativa respecto del discurso memorial de Polo:

Tiempo de hablar de tu matrimonio. Lo que tenía que suceder, sucedió. Todo un médico cirujano y partero y nunca se te ocurrió pensar que los babies se hacen en la cama. Una mañana, en vez de ir al trabajo, sin avisarle a nadie más que al nuevo interno del asilo que te acompañó en tu aventura, que te sirvió de padrino, te casaste en un pueblo cercano a Puntarenas (450).

Para Bajtín (Todorov 1981: 294), aún los pensamientos más íntimos, los del discurso interior, están orientados hacia un auditorio y son, por tanto, dialógicos:

Et, pour s'en convaincre, il suffit de considérer que, lorsque nous nous mettons à refléchir sur un sujet quelconque, lorsque nous l'examinons attentivement, notre discours intérieur (...) prend immédiatement la forme d'un débat par questions et réponses, fait d'affirmations suivies d'objections; bref, notre discours a' analyse en répliques nettement séparées et plus ou moins développées; il est prononcé sous la forme d'un dialogue.

Cette forme dialogique apparaît clairement lorsque nous avons à prendre une décision. Nous sommes pleins d'hésitation, nous ne savons pas quel parti adopter. Nous engageons une discussion avec nous mêmes, nous essayons de nous convaincre nous-mêmes de la justesse de telle ou telle décision. Notre conscience semble ainsi nous parler par deux voix indépendantes l'un de l'autre, et dont les propos sont contraires (Los subrayados son nuestros).

Es este elemento sociológico inherente a la conciencia humana y su estructura semiótica lo que se tematiza en $M P$. He aquí algunos de esos diálogos en el interior de la conciencia:

...el viaje a Acapulco con Golda fue primero, Polo cabezón como tu madre; el viaje a Costa Rica fue al año siguiente, en julio. Te diste de vacaciones todo el mes como te sugirió Golda. No seas necio el viaje a Acapulco fue en octubre (428).

Después de esos viajes al Hospital Central, te sientes más apabullado que nunca. Sabes que se acerca el día en que tendrás que rotar por ahí, hacerte cargo de los pacientes, de las estrellas, de los genios del programa, de Rosen, de los miembros de la trilogía, de los pacientes del hombre del pantalón ancho y arrugado... ¿Qué vas a hacer entonces? ¿Cómo les vas a hablar a estas gentes cuyos médicos los tratan con tanta gentileza, con tanto decoro, con una sonrisa siempre a flor de labio? ¿Cómo se va a oír tu inglés en ese templo del saber, tu inglés estancado donde empezaste a trabajar en la sala 14 ? (491).

El sujeto bajtiniano se da entre la oposición y la equivalencia, ya que es un yo como yo pero es un otro yo, el otro es un no-yo; se juega, pues, entre la refracción y la identidad. De ahí que se podría afirmar que el "nosotros" no es tú ni yo, sino más bien la reunión de los "yoes". 
Por eso en $M P$ esa segunda persona que es Polo pasa sin transición alguna a la primera de "el que escribe" dentro del mismo enunciado:

Empezamos a pelear. Sin embargo, aguantaste los embates. La experiencia con Susana te había enseñado una gran lección. $\mathrm{Ni}$ a putas iba a permitir que me pasara otra vez lo mismo. (...) Ahí viviste seis o nueve meses. Seis o nueve meses de lucha campal conmigo mismo y con Golda: siempre borracho, siempre metiéndome coca y siempre deprimido (459).

Lo único claro, cristalino como el agua, es la importancia de tu trabajo, la necesidad de conservarlo. El salario es bueno, más de lo que ganabas de interno en tu país. Aquí el trabajo es en serio: ocho horas diarias bien metidas, sin siesta al medio día. Trabajo tanto, con tanta concentración, con tanto cuidado, que no me doy cuenta de las mujeres a mi lado (473).

Despúes de que desayunas te agarras a la grabadora de tu amigo y estudias inglés, un curso de la Universidad de Ann Arbor que Walter te ha recomendado con entusiasmo y que él también estudia por las noches, después de que regresa del trabajo (¿cómo se dice, quiero ir de tiendas? I want to go shopping). Después de escuchar inglés por dos horas, acometo la peor de mis obligaciones: estudiar medicina en un idioma que no conozco (466).

Según Goldmann (1984), cuando Descartes dice "ego sum ego existo", pone de relieve ese "ego" que quedará como fundamento de toda filosofía racionalista o empirista hasta nuestros días. El ego, por ser el primer dato fundamental, el punto de partida (la conciencia de la propia conciencia: pienso luego existo), el problema de las relaciones entre los otros, cuando se presenta se convierte naturalmente en el problema "ajeno". Los "otros" hombres se hallan asimilados a la realidad física y sensible. Los otros no son más que seres que yo veo y oigo, como veo la piedra que cae y como oigo su caída.

En Bajtín, todo lo contrario: si bien el otro es radicalmente distinto del yo, es un otro yo; sujetos los dos.

La otredad bajtiniana se define como la afirmación del yo del otro no como un objeto (un tú), sino como otro sujeto (un otro yo). De ahí que la dialogía de Bajtín se puede entender como la igualdad de los sujetos en relación con la verdad.

Creemos que un ejemplo singular de este acontecimiento se da en esta obra de V. A. Mora Rodríguez. La radical diferencia entre esas dos conciencias que dialogan, y que por esa diferencia dialogan, es que Polo no conoce a tiempo las "puntas" de las cumbres del tiempo, mientras que "el que escribe" sí las reconoce gracias a su madurez (en estas citas que siguen los subrayados son nuestros):

En el lugar pululaban las gentes que habían publicado trabajos en todas las revistas académicas del país y que hablaban de neurofisiología y neuroanatomía desde que salía el sol hasta que se ponía. En el departamento la consigna era publicar. A esa función se encaminaban casi todas las actividades. Un investigador silencioso, era un hombre finito. Ahí llegaste, Polo, una mañana de noviembre en tu Chevy y con el almuerzo en una bolsa de papel, listo a meterte en el berenjenal más grande de tu vida... (480).

Se llegó el momento de recrear otra vez en la memoria, el cataclismo, revivir nuevamente, donde sea posible, la experiencia, los setecientos treinta días de enajenación, que empezaron aquella mañana, aquel primer día de julio en que te paraste por primera vez en el City Hospital, listo a empezar tu entrenamiento de neurología (484). 


\begin{abstract}
No entiendes qué sucede, cómo es posible la pobreza con tanto dinero. Como todos los extranjeros procedentes del tercer mundo, te entregas con ímpetu, apenas empiezas a ganar dinero, al ejercicio de la operación aritmética más excitante, la multiplicación de los panes, la conversión en dólares a la moneda de tu país, olvidándote de que ahora vives aquí, en U.S.A. (474).
\end{abstract}

Pero "el que escribe" es producto de las reiteradas praxis de Polo sobre el mundo y es el hacer de este quien le proporciona ese saber maduro por medio del cual "el que escribe" se pronuncia sobre el hacer de Polo. En "el que escribe" se concentra todo lo antes vivido y mucho del porvenir, pero este, su futuro, la vida que debe seguir viviendo, sólo podrá vivirlo de ahora en adelante con Polo y a pesar de este; lo que suceda después, Mano a mano lo dirá (Mora 1998).

Por otra parte, "el que escribe" ya se adivinaba en la existencia de Polo cuando en medio de su ceguera vital afirma:

Algún día me gustaría escribir sobre mis experiencias, hablar de mi vida, de todo lo que siento ahora... (305).

Esta necesidad de la escritura es la que va a llevar finalmente al desprendimiento de sí, que es la exotopía. Para Foucault "uno escribe para convertirse en otro distinto de quien es" (Miller 1995: 47). Por lo anterior, podríamos afirmar que en MP se develan las regulaciones internas del discurso con la esperanza de descubrir en sus entrañas el enigma del ser; de ahí que la narración sea un proceso que se cuestiona constantemente a sí mismo:

\footnotetext{
Estás un poco pensativo, Polo. No sabes cómo continuar el relato. Tal vez el recuerdo de las dos mujeres te dejó descorazonado. ¿Qué te pasa? Quizás tienes temor de seguir adelante, porque ves aproximarte a pasos agigantados la muerte de tu padre. No tenemos que hablar de ella en este momento. Podemos tomar el avión en El Coco, aquel lejano octubre en tu segundo viaje a la patria... (436).
}

Recuerdas muy bien tu primer rompimiento con ella. Por supuesto: durante nuestro segundo viaje a Nantucket. Lo que no recuerdo es si ese viaje precedió a aquella semana en Fire Island con Georgie Boy y la Jackie. Tú siempre preocupado por la cronología de los hechos... (451).

Lo que esta narración autodubitativa pone de manifiesto es que el ser, la verdad sobre uno mismo "no es algo que esté allí, algo que se pueda hallar o descubrir, sino algo que hay que crear" (Deleuze. En Miller 1995). La creación de la identidad en MP se efectúa entonces a través del diálogo y por medio de este el sujeto se abre a las multiplicidades que lo atraviesan. $M P$ se afilia a esta fenomenología foucaldiana de la escritura que desmantela nietzscheanamente la idea del sujeto unitario. Entre Polo y "el que escribe" se elabora sin mistificaciones la idea de un sujeto hecho de retazos, un sujeto compuesto, como los retratos de Arcimboldo, que se ofrece ante la mirada atónita del lector de forma anamórfica. Tanto Polo como "el que escribe" intentan darle forma al caos de fragmentos e imágenes sueltas de lo vivido. El problema estriba en que no hay absoluto acuerdo entre ambos, pues en esa "experiencia interior cada cual respira en medio de un atónito murmullo de discursos contradictorios provenientes de culturas y experiencias diferentes, y entre los dos se oculta el daimon de una culpa. 


\title{
3. Modos genéricos de la rememoración y sus cronotopos
}

$M P$, como ficción autobiográíca, señala en efecto el momento daimónico de un cruce de caminos, el de Polo y el de "el que escribe". Polo es "ese otro" cuya vida y errores han sido superados aparentemente por "el que escribe". En ese sentido, $M P$ se construye sobre la tradición de un género biográfico más específico: el de la autobiografía picaresca.

Antes de entrar en el examen genérico de $\boldsymbol{M P}$, creemos necesario hacer unas acotaciones sobre el concepto bajtiniano de "cronotopo" y la forma en que aquí va a ser comprendido y aplicado.

El estudio del cronotopo está inserto en un capítulo del libro Estética y teoría de la novela (Bajtín 1989). El título de dicho capítulo es "Formas del tiempo y del cronotopo. Ensayo de poética histórica". Bajtín lo define así:

\footnotetext{
Vamos a llamar cronotopo (lo que en traducción literal significa tiempo-espacio) a la conexión esencial de relaciones temporales y espaciales asimiladas artísticamente en la literatura (...) Entendemos el cronotopo como una categoría de la forma y el contenido en la literatura (Bajtín 1989: 237).
}

Como se ve, nada mejor que esta noción para examinar una novela como $M P$, tejida a fuerza de traslaciones temporales y espaciales tan abruptas. En este relato, la correlación espacio-tiempo es esencial ya que su estructuración se nos presenta sobre la base de un "aquî"/“allá" y de un "antes"/ "después" que se invierten y revierten en un juego anatrópico que implica no sólo la transformación de la evaluación de los eventos vividos, sino también una transformación del sujeto que los vive:

\begin{abstract}
Antier lunes se cumplieron veinticinco años de tu llegada a Saint Louis. No dijiste nada. No quieres hablar de tu experiencia en ese lugar. Entonces no te conocía. Sin embargo, lo imagino todo: el hombre joven, candoroso, ajeno a la existencia de prejuicios entre "blancos", desembarcando en un lugar donde nadie hablaba español... (465).
\end{abstract}

Para Bajtín, en el cronotopo, como categoría literaria, se da la fusión de los índices espacio temporales en un todo inteligible y concreto. Allí el tiempo se condensa, se hace compacto, se convierte en visible desde el punto de vista artístico; mientras el espacio se intensifica, penetra en el movimiento del tiempo, del argumento, de la historia. Los índices del tiempo se describen dentro del espacio y este se percibe y se mide según el tiempo. En otras palabras, los elementos del tiempo se revelan en el espacio y el espacio es entendido y medido a través del tiempo. La imagen del hombre en literatura siempre es una imagen espacio-temporal, dice Bajtín; por lo tanto, a través del análisis del cronotopo también tendremos acceso a la específica concepción del hombre que se encierra en un género y en una época (Bajtín 1989). De la misma forma en que Bajtín intentará caracterizar a través de los cronotopos el universo novelesco y los diferentes géneros a los que da lugar, nosotros intentaremos caractenizar el universo de MP y el sujeto identitario a que da forma a través de sus cronotopos.

En literatura, el cronotopo tiene una importancia capital para los géneros; se puede decir que esos, con su heteromorfismo, están determinados por el cronotopo.

Así, el género es un campo de representación que se delimita como espacio y como tiemBajtín coincide con Kant en que tanto el espacio como el tiempo son formas indispensables 
para todo conocimiento, comenzando por las percepciones y representaciones elementales; pero, si bien estas formas tienen gran significación en el proceso del conocimiento, Bajtín no acepta que sean "trascendentales", ya que, según él, son formas de la realidad más verdadera o cierta. Así, los cronotopos literarios se alimentan de una cierta forma de los cronotopos históricos, los cuales son los factores epistémicos que orientan el conocimiento del mundo en una época dada.

En otras palabras, se puede decir que el cronotopo es la materialización espacio-tiempo de los diferentes acontecimientos que integran la obra y son los cronotopos los que delimitan o caracterizan las diferentes especies genéricas, pues el cronotopo no se limita a señalar únicamente el lugar del acontecimiento, sino que además muestra la forma de organizar y materializar su representación. Por lo anterior, podríamos decir que el cronotopo es la forma histórica de la textualización, es decir, que por su intermedio, la dimensión estética de lo social en el texto se ancla en un específico lugar de la historia.

Según Bajtín, hay dos clases de género: unos primarios o simples, constituidos en la comunicación social inmediata (lo que recuerda algunas de las "formas simples" de Jolles (1972): ironía, chiste, caso, enigma, etc.) y otros secundarios o complejos que surgen en condiciones de una comunicación cultural más compleja y relativamente desarrollada, organizada, que es una comunicación esencialmente escrita, de carácter artístico, científico, social y político. En el proceso de formación integran en sí mismos y transforman los diferentes géneros primarios. Genette (1979) llamaría "modus" a los primeros y géneros "propiamente dichos" a los segundos. Según el teórico francés, la diferencia entre unos y otros es la siguiente: los modos serían "formes a priori de l'expression littéraire", "des catégories linguistiques et prélitteraires"; mientras que los géneros serían instituciones sociohistóricas y entre ambos se daría normalmente una especie de "intersección" (75-9).

Los géneros complejos, asentados en el entramado más básico de la lengua, son, sin embargo, el resultado de una específica labor de composición en la que "el cierre" entraña, según nos enseña Bajtín, suma importancia:

El problema del acabado es uno de los más esenciales en la teoría de los géneros. La subdivisión de las artes particulares en géneros viene determinada en gran medida por los tipos de cierre de la obra entera. Cada género es una manera particular de construir y acabar el todo — siendo lo esencial, repitámoslo, acabar temáticamente y no convencionalmente solo en el plano de la composición. Cada género es un sistema complejo de medios y de maneras de tomar posesión de la realidad, para darle un acabado comprendiéndola enteramente. El género es el conjunto de medios de una orientación colectiva de la realidad con vistas a su cierre (Bajtín-Medvedev 1994).

Por eso, para Bajtín los géneros tienen un gran valor heurístico al proveer un modelo del mundo. Cada género posee sus métodos y sus modos de ver y comprender la realidad "a través de los ojos del 'género"". Esto nos permite preguntarnos por cuáles son las realidades sociales que en un momento dado invitan a unas formas y prohiben otras, cuáles son los temas que pueden ser tratados en una determinada estructura o cuáles aquellos que de hecho no se han intentado nunca o sus intentos han resultado fallidos... ¿Por qué este texto y no otro, en esta época?

Según Bajtín, desde la Antigüedad se dieron tres cronotopos novelescos fundamentales: 
1. La novela griega (también conocida como la novela sofista) sucedida por la novela bizantina y evolucionada en la llamada novela barroca de los siglos XVII y XVIII.

2. La novela de aventuras y costumbres, cuyo paradigma es El asno de Oro, de Apuleyo, y El Satiricón, de Petronio.

3. La biografía y autobiografía antiguas.

Esos cronotopos corresponden a la etapa antigua de formación de la novela, pero tienen gran importancia en la comprensión de la naturaleza de esta. Por eso, es a partir de ellos que Bajtín explica el devenir de este género, al que caracteriza esencialmente como no canónico. Según el maestro ruso, la novela es un género que "se está investigando eternamente a sí mismo y siempre está reconsiderando todas sus formas establecidas" (Bajtín 1989: 553); esa es la razón por la cual todos los géneros empiezan "a sonar de manera diferente" a partir de ella.

Para Bajtín, la novela adquiere su perfil moderno en el Renacimiento gracias a una reorientación que se podría esbozar de forma esquemática como sigue:

1. Aparición de un hombre con iniciativa ideológica y lingüística, por lo cual varía el carácter de su imagen en la novela.

2. Aparición de la subjetividad por medio de la divergencia entre el hombre externo y el interno. Esto hace que el hombre se convierta en el objeto de la experiencia y la representación, y emerja la posibilidad de la confesión-desenmascaramiento.

3. Aparición del presente como continuación inacabada del pasado y más cercano al futuro que a este. De ahí la capacidad profética -agregaríamos nosotros- de la novela actual, su potencial para anticipar los ideologemas del porvenir.

Todas las transformaciones antes mencionadas fueron posibles gracias a la ruptura de la distancia épica, la cual se fundamentaba en el pasado absoluto. Lo anterior trae como corolario también la ruptura de la distancia jerárquica y con esto se abre la posibilidad de un gran dinamismo en el género, su constante plasticidad, hasta el punto de que se podría afirmar que lo novelado resultan ser los géneros mismos, como sucede en caso de $\boldsymbol{M P}$. Las siguientes palabras de Bajtín parecieran, por ende, referirse a la novela que tenemos en estudio:

\footnotetext{
El novelista tiende a todo lo que todavía no está terminado. Él puede aparecer en el campo de la representación en cualquier pose autoral, puede representar momentos reales de su vida o hacer alusiones a ellos, puede inmiscuirse en la conversación de los héroes, puede polemizar abiertamente con sus enemigos literarios, etcétera. La cuestión no está solo en la aparición del personaje del autor en el campo de la representación, sino que también el autor verdadero, formal y primario (el autor de la imagen autoral) resulta hallarse en nuevas interrelaciones con el mundo representado: se encuentra ahora en las mismas dimensiones valorativo-temporales, la palabra representadora del autor descansa en un mismo plano con la palabra representada del héroe y puede entrar (más exactamente, no pude dejar de entrar) en interrelaciones dialogales y combinaciones híbridas con ella (Bajtín 1989: 539).
}

Esa es la plasticidad genérica que presenta $M P$, un relato que, alimentándose de los géneros canónicos, los descanoniza. Así, por ejemplo, de la novela de pruebas y aventuras $\mathbf{M P}$ hereda los cronotopos de la huida, del viaje y del país extraño, los encuentros y los reencuentros; pero las huellas que dejan esos cronotopos en sus agentes y sus metamorfosis se reacomodan en formas más propias de la novela que Bajtín llama "costumbrista o de aventuras"; no 
es, sin embargo, este género el que delínea el cronotopo ni la estructura prevaleciente en $M P$, pues al quedar la vida fuera de los límites del relato, la novela de Mora se entronca más bien con la novela biográfica y autobiográfica con sus épocas delimitadas, el camino vital que se recorre a través de la ignorancia segura de sí misma en Polo, hasta el escepticismo crítico de "el que escribe" y el conocimiento de sí mismo que es buscado por ambos.

Pero aún este género y sus cronotopos son deconstruidos en $M P$ y a estas transformaciones nos referiremos enseguida.

Ya habíamos visto cómo, a pesar de que en $\boldsymbol{M P}$ se representa un tiempo biográfico, la alegoría de las edades, que es propia de ese tiempo, el ciclo biológico, natural y vital, es sustituido por imágenes diferentes que son separadas por sus crisis, cambios geográficos y culturales. Las series temporales y espaciales son bastante enérgicas y se estructuran mediante cruzamientos que se propician a través de otro cronotopo: el del umbral. Este cronotopo se rellena normalmente con las crisis y las decisiones que cambian el rumbo de la vida, crisis a las que ya nos hemos referido como momentos kairológicos que señalan los virajes del camino vital. El cronotopo del umbral se concreta en $\boldsymbol{M P}$ por medio de un espacio inédito, epítome de los encuentros y las despedidas, umbral de la distancia y lugar también de los recuerdos de otros encuentros y despedidas: el aeropuerto y el avión. Ellos son los espacios en que el tiempo parece salirse del curso normal del tiempo biográfico y, sin embargo, son los conectores y marcadores de las etapas que en él culminan para iniciar otras que, en ciertos casos, van a propiciar encuentros casuales como los que se dan en el cronotopo del viaje y las aventuras. Por medio de esos umbrales, vemos condensarse el tiempo de la vida humana como tiempo histórico y por ellos los valores espaciales se trasladan a relaciones temporales; tal vez no hay forma más sintética de ilustrar la trasposición del valor espacial al temporal que aquel telegrama que envía uno de los compañeros de Polo a su familia el día que llega por primera vez a México: "Llegué bien. Estoy más gordo".

La velocidad con que se sucede el tiempo, los cuadros estáticos de ciertas imágenes, hace que la rememoración se despliegue como una película, según el principio del cinematógrafo:

Tú tratas de reconstruir lo que sucedió ese primer día. Hay que aclarar que lo que ahora cuentas es algo así como el relato de un hombre que presencia una película muda, sin subtítulos, al que se le pide que narre la historia, el argumento de la cinta (486).

Después de mi paso por el departamento de neurología, de la película muda de esos dos años aciagos, faltan varios rollos, pierdes el hilo del argumento de la cinta hasta el siguiente otoño cuando lo recobras en el servicio de Psiquiatría del Hospital Central (493).

Si Bajtín anunciaba la entrada de la novela a una nueva fase, y si los cronotopos literarios asimilan ciertas formas del cronotopo real que ciertas condiciones históricas ponen a disposición, en $M P$ el cine y la extrema movilidad de las imágenes visuales que es su fundamento evidencian ese cambio, que es no sólo genérico sino epocal. Tal vez entre la literatura de finales del siglo XIX y la del XX, la diferencia sea entre dos medios ópticos, dos tecnologías de la visión, el de la fotografía y el del cine; como tal vez lo sea también la diferencia entre el papel del tren del siglo XIX y el del avión en el siglo XX. No en balde el avión y el aeropuerto son los constituyentes del cronotopo umbral en esta novela de Mora. 
Gracias a la cinematografía, en $\boldsymbol{M P}$ lo estático espacial se inserta en la serie temporal no sólo de los hechos representados, sino también del propio relato-representación. Esa influencia explicaría también los cortes de la historia, su pretensión de ubicuidad y sincronía de diferentes momentos de la vida, la aceleración de los hechos vividos, la enorme cantidad de experiencias; como también refractaría el cambio que en el sentimiento y captación del tiempo se ha dado en la época de la que la novela es tributaria (por ejemplo, en el caso del famoso telegrama).

Tal vez sea este efecto cinemático el que marque esa nueva etapa que de la novela anunciaba Bajtín. Al respecto, Paul Virilio, el famoso arquitecto creador de la "dromología", afirma:

La velocidad trata la visión como materia prima, con la aceleración viajar equivale a filmar; no tanto producir imágenes cuanto huellas mnemónicas nuevas (1988: 67).

Así, el viaje conciencial de $M P$ se despliega como el espectáculo de una pantalla. A la sobreimpresión (técnica del cine mudo para exponer los sentimientos y pensamientos del actor haciendo pasar sobre el rostro de este los paisajes y sucesos en los que está pensando), le sucede la panorámica y el "travelling"; de la misma forma se produce en $M P$ el vértigo espacial y temporal y una cierta forma de ubicuidad en la que las series espacio-temporales pierden su absolutez. La influencia de la cinematografía será todavía más evidente en otros relatos de Mora, como es el caso de La película y Mano a mano.

Además del cronotopo del umbral, se inserta también el cronotopo del idilio, aunque este es asumido bajo ciertas matizaciones. Aparece inevitablemente en el resumen de la infancia, pero de él conserva tan sólo el tiempo folclórico y algunos de sus elementos externos como las montañas, los campos, los ríos y la casa natal, esta última descrita con cierto rebajamiento, afectada como está por la miseria y una relación familiar carente de afectos. Es esta variación la que induce el relato hacia la autobiografía picaresca, como ya lo habíamos afirmado, pues las debilidades del mismo cronotopo idílico, la limitación del espacio local y sus posibilidades conllevan a la huida, a la búsqueda del exotismo, de "lejanos países y lugares nuevos". Así, se pasa del terruño, de la aldea, hacia la gran urbe, la vida cosmopolita, en búsqueda ansiosa de novedades. Pero el protagonista regresa al terruño transformado por sus aventuras y por la nueva visión que tiene de la vida y del mundo, de ahí la sensación de extrañamiento que va a provocar una segunda huida y una transformación más acentuada. Este es el comienzo de la crisis mayor que va a conducir hacia la confesión final ante el terapeuta y el acto de escritura. El relato es confesional en tanto entraña una culpa y un deseo de exculpabilización.

Al igual que en la novela picaresca, y creemos que este relato ha sido construido siguiendo ese prestigioso canon que da inicio a la novela en lengua española y que la marca para siempre, la instancia narradora de Memorias de un psiquiatra se mira como la conciencia de una vida superada en las experiencias que se relatan y que observa el pasado de sí misma con cierta compasión por la ausencia de sentido con que se vivieron esos hechos, sobre todo los errores, y se da entonces un enjuiciamiento de esa vida pasada y su personaje, que es un otro, un hombre diferente de este otro que narra desde el atalaya del futuro y que le permite ver a ese otro en toda su completud. 
Sin embargo, como lo decíamos, hay al mismo tiempo una ruptura diferencial con el canon picaresco y es que si bien se enjuicia al otro, al final no se le rechaza ni se reniega de él como sí lo hace, al menos de manera explícita, el yo picaresco; todo lo contrario, más bien se asume en su otredad y sólo por esto es que la estructura dialógica y exotópica tiene lugar y se justifica. De ahí también la exculpación, los artificios de desculpabilización que veremos más adelante.

El otro quiebre diferencial estriba en que mientras la novela picaresca trata de ocultar la ficcionalidad con la autobiografía, en la obra de Mora se pone en evidencia su carácter de ficción al separar la voz narradora del protagonista, por una parte, y al insistir, por otra, en que ambos son un mismo individuo aunque sean dos conciencias diferentes, o una sola en dos planos diferentes de autocomprensión. Lo anterior significa una ruptura con la práctica literaria de donde el texto extrae su lógica: la novela picaresca, la cual era ya una subversión de una práctica sociodiscursiva de su tiempo, como la han demostrado prolijamente Gómez Moriana (1985) y Edmond Cros (1990: 22-45).

Según Cros, el ideosema, el elemento articulador entre las prácticas sociales y los fenómenos semióticos textuales, se muestra en la novela picaresca española como una subversión de la práctica confesional instaurada por la Inquisición, denunciando los virtuales efectos ficcionales que ella podría implicar. $\boldsymbol{M P}$ desenmascara a través de la confesión, las convenciones culturales y su fuerza subjetivadora e intenta conducir al sujeto, no a su renuncia, sino a su perdón, asunción y epifanía. Lo anterior es posible porque el relato confesional se elabora aquí a través de un subentendido psicoanalítico que, no obstante, no está en situación clínica. La escritura sustituye a la clínica y objetiva la culpa a través de la creación de Polo. En este fantasma se concentran los recuerdos del pasado tal y como han sido formados en las etapas posteriores de evocación y que no tienen nada que ver con la verdad histórica sino más bien con una serie de "motivos" que son los responsables de la selección misma de los recuerdos. Esos motivos son los de una culpa que se instala ante el sentimiento de traición con respecto a ciertos valores culturales. Si en el caso de la confesión inquisitorial se trataba de una conversión religiosa y de un asunto de fe, en la situación de $\boldsymbol{M P}$ se trata más bien de una conversión cultural y de un asunto de libertad personal. El relato confesional se imbrica, entonces, en la novela de Mora con una identidad afectada por un choque cultural que sólo es posible en el presupuesto de la existencia de identidades nacionales y de horizontes ideológicos específicos y diversos.

Según Castilla del Pino (1981: 47), "la culpa se refiere a una acción determinada del hombre mediante la cual (...) se viola un principio rector, el hacer debido".

El principio rector en referencia al cual se juzga una acción culpable evidencia el carácter sociogénico de esta, ya que ese principio rector transgredido pertenece al código social que regula la convivencia cultural de la comunidad de la que el individuo se considera parte; por eso, también debe destacarse que ese principio rector, en consecuencia, es vivido como rector por el sujeto mismo.

En el primer fragmento introductorio de la novela, titulado "La distancia del último adiós" se describe el origen de la culpa, como también se exponen las formas de exculpación que el protagonista ensaya, todo en un esfuerzo inútil por liberarse de ella. Ante el fracaso de la situación clínica, aparece la escritura como terapia y así se genera la motivación implícita en contar la historia de su vida y escribir las Memorias de un psiquiatra. 
La situación clínica inicial es fallida porque el paciente no encuentra comunicación con el terapeuta, dado que el médico es miembro de una cultura diferente de la del paciente, y este así lo señala:

Usted no entiende. Usted es de aquí: americano desde que nació. Toda la vida todo le ha sobrado. Usted no sabe lo que es vivir con una mano aquí y otra atrás (2).

De modo que la expresión de la culpa no encuentra atenuantes y el proceso de exculpación no se puede producir debido a que el terapeuta desconoce el código de referencia que podría clasificar los hechos del paciente como él se los presenta: como hechos culposos.

El origen de la culpa en $M P$ tiene su asiento en un valor cultural: el valor de la familia y las obligaciones que las relaciones familiares encarnan. Entre esos valores se destacan el papel filial, el papel marital y el papel paternal.

En el anterior análisis del relato titulado Los problemas del gato, se expusieron los motivos sociales que impulsaron, por ahí de los años cincuenta, a un gran número de jóvenes costarricenses a estudiar medicina en México; en otras palabras, expusimos la orientación o determinación social del proyecto vital de esos jóvenes. La revolución del 48 en Costa Rica, que es un leit motif en las obras de Mora, inició una transformación social acelerada que permitió la aparición de una clase media antes inexistente. Los requisitos de ascenso a esa clase se basaban en la adquisición de una profesión; pero al tener la profesión médica, una solera reputación tanto económica como política en la evolución social del país, muchas familias de escasos recursos quisieron apostar, para sus hijos, precisamente por esta profesión y no otra. México fue el receptor de cientos de estudiantes costarricenses que, como Polo, "alcanzaron el cielo con las manos" al regresar al país graduados como médicos y encontrarse, por ese mismo hecho, de repente catapultados a una esfera social de mayor prestigio que coincidía con un desarrollo sin precedentes en el sistema de Seguridad Social, de atención a la salud de la población y de extensión del sistema hospitalario nacional.

La inconsciencia con que Polo toma la decisión de convertirse en médico es así declarada en el relato de su vida mediante la voz de "el que escribe":

Durante tu rotación en la Caja del Seguro, confirmas lo que ya habías adivinado en México: la medicina te interesa muy poco; te hiciste médico porque estaba de moda. De la medicina te gustan sólo los pacientes, la gente que sufre. Disfrutas sobre manera el trato con los pacientes del Asilo. Ahí te asombra la variedad de sus problemas y su complejidad (455).

Es en ese momento que nace no sólo la vocación de psiquiatra de Polo, sino también el germen de una novela de Mora que conocemos desde hace ya rato: Cachaza (1979).

Empiezas a interesarte por la gente que internas; te sorprende la actitud, la falta de respeto que exhiben ante los enfermos, muchos de sus familiares y algunos de tus colegas. El Asilo es un mundo aparte. Nadie -ni tú antes de empezar a trabajar ahí- puede imaginar lo que hay más allá del frontispicio de iglesia que evoca paz, tranquilidad espiritual (455).

También en Los problemas del gato observamos el sacrificio que implicó para estos padres de los cincuenta hacer realidad su proyecto, a tal punto que la historia de ese relato la resumimos como una historia de crueldad filial, dado que en ese caso el hijo desperdicia las 
oportunidades que se le ofrecen sin importarle lo que ello significaba para la vida de sus progenitores. El papel de la madre en ese relato es muy similar al de la madre de Polo en $\mathbf{M P}$ : ella es el agente activo no solo en la elaboración del proyecto vital de su hijo sino también en gran parte de su ejecución. Polo describe así a su madre:

Nos usaba (a él y a su hermano) para exhibir en el pueblo su buen gusto, su limpieza... Su esmero en que no nos ensuciáramos, en vestirnos con trajecitos de marinero y zapatitos blancos, satisfacía su necesidad, no la nuestra. Lo que nosotros necesitábamos era cariño, palabras, cuentos a la hora de acostarnos. De eso ella no tenía nada; lo mismo el viejo (27).

\section{Así, Polo le confiesa al terapeuta:}

No sé por qué me decidí a estudiar medicina, pero es muy posible que mi madre lo insinuara de alguna manera. La vieja nos controlaba al viejo y a mí de una manera poco sutil. Yo le tenía miedo. Al viejo lo manejaba a través de sus enfermedades (siempre estaba enferma)... Nunca olvidaré su coraje o su ingenuidad. Cuando terminé mis estudios secundarios, el día de mi graduación, me montó en un camión que nos dejó cerca de la embajada de un país suramericano. Mi madre tocó a la puerta de la embajada y preguntó por el embajador. El embajador no está informó uno de sus sirvientes. Mi madre quería que me dieran una beca para estudiar medicina (19).

Y la madre se sale con la suya. Polo regresa de México hecho médico pero no logra resistir el cambio radical de su valoración social, ajena por completo a la clase de donde procede; por eso le dice al terapeuta que él no entiende, no puede entenderlo:

Me arruinó la fama. Siete años de vacas flacas, la plaga en México, Distrito Federal. Súbitamente, médico, cirujano y partero en mi país. No aguanté el shock. Me descontroló. Me casé. No supe lo que hacía, doctor (2).

Mi matrimonio fue un acto irreflexivo, una forma de arreglar las cosas de la única manera que nosotros sabíamos: a la latina (4).

Su matrimonio es resimbolizado como una traición a sus padres, pero especialmente a su madre, por las razones que ya apuntamos:

Los pobres viejos, casi analfabetas, se habían sacrificado al infinito para tomar de la vida, con mi ayuda, lo que esta jamás les había ofrecido. Así fue como me hice médico. La noche que salí de la casa de ellos a escondidas para casarme, les di con la puerta pesada de la realidad, en las narices... (5).

El deseo de ascenso social y el alejamiento de sus padres es otro de los motivos picarescos que encontramos en $\boldsymbol{M P}$.

La segunda huida del protagonista, esta vez hacia los Estados Unidos, responde un poco a evadir ese pesado sentimiento de culpa, pero allí realiza otro acto culposo: la separación de su mujer y el abandono de sus hijos:

¿Cómo confesarles que me sentía como un gusano? ¿Cómo pedirles perdón? ¿Cómo, doctor? De alguna manera me creía la persona más culpable del mundo -ya se lo dije antes-, sentía que había traicionado a mis padres para toda la vida. En esos días andaba de fiesta en fiesta para apagar mi culpa igual que ahora (...) La guerra con mi culpa apenas había empezado. Siempre culpable desde entonces. Y ahora mis hijos, mi esposa... La misma sensación: culpable. Soy un gusano (9). 
De esta forma, MP es un relato de inculpación y exculpación, un relato confesional que, como el de la picaresca, proyecta en lo social y sus convenciones el origen de la culpa. La escritura ejerce una función terapéutica de auténtica catarsis a través de un otro, que no es precisamente el terapeuta, sino el sujeto cultural instalado en el fondo de su conciencia, el único capaz de inculparlo pero también el único capaz de comprenderlo.

Esta conciencia culpable intenta diversos modos de desculpabilización, tales como aquellos que Herra (1993) denomina y clasifica:

1. Complejo socrático: actué mal pero fue por ignorancia, no estuve al tanto de las consecuencias de mi acción.

2. Ideología de las pulsiones: lo hice, pero deben comprender que no puedo controlar mis impulsos.

3. Coartada comunitaria: lo hice, pero es que así se hacía allá y así se hace aquí.

4. Dramaturgia del deber: mi situación me obligó a actuar así.

Es la exotopía lo que le permite al autor de las memorias una clara objetivación de sus motivos personales (formas de exculpación 1 y 2) y de los motores sociales (formas de exculpación 3 y 4) que le indujeron a cometer sus errores; de ahí que el resultado obtenido a través de la ficción es objetivar la culpa en Polo y resolverla estéticamente para vivir con ella en la sublimación que la escritura le permite efectuar al hacer de la vida una novela. Así aprende "el que escribe" a vivir a pesar de la culpa y dejar de vivir exclusivamente para ella.

El tema de la culpa es en $M P$ muy coherente con el papel que ahí juega el tiempo, y al que nos hemos referido, de la misma forma que es coherente con las series espaciales y las funciones que para ellas hemos descrito, especialmente como elementos cronotópicos.

En cuanto a las series espaciales, que marcan radicalmente la fragmentación del tex, tanto con el cronotopo del "viaje" como con el "mundo ajeno" que en él se implica, ellas e generan narrativamente a partir del sentimiento de culpa y van a permitir un diálogo no sóentre las dimensiones temporales, sino también entre los espacios socioculturales, pues, coo ya vimos, se trata de un sujeto de exilio, un sujeto culturalmente converso, atrapado entre códigos culturales diferentes que exigen reacciones también diferentes ante situaciones nuemas. Por eso aparece ahí también el factor necesidad que, frente a nuevas condiciones matefales o culturales, obliga a resimbolizar los códigos primordiales del sujeto, lo cual se lleva a abo, como lo obvia $\boldsymbol{M P}$, no sin conflicto. Se trata de una renegociación simbólica que inclue artificios de exculpación como los descritos bajo las rúbricas de la "coartada comunitaria" "dramaturgia del deber".

La problemática anterior significa una nueva variante en los géneros antiguos, pues novela moderna, especialmente la de este siglo y en Hispanoamérica, ante la nueva reacomodación espacial y temporal introducida por los nacionalismos y la emergencia del Estadokación, hace del cronotopo del "viaje" el motivo del exilio; y del "ajeno país", el motivo de - crisis de identidad cultural. Además, esos cronotopos se encuentran actualmente en un momento de transición debido a los procesos de globalización económica y la renegociación que exige sobre el tema de las identidades. Esta nueva cartografía del mundo contemporáneo el que los mapas se están reelaborando de modo que incluyan la dimensión temporal, exigen transformación bastante drástica de los antiguos géneros y de su relación con el tiempo y 
los nuevos espacios cartografiados, lo mismo que en relación con los nuevos espacios electrónicos y formas diferentes de viaje, particularmente en los espacios cibernéticos (la introducción de esta nueva transformación del espacio es observable en otra novela de Mora titulada Mano a mano). Al igual que en la novela de Mora, la aceleración de los cambios tiene mucho que ver con en las formas de configurar y reconfigurar el tiempo narrativo.

En el caso del tratamiento del tiempo en $M P$, por ejemplo, la pesadumbre que genera la culpa explicaría la dilatación del presente con el afán de asimilar y comprender la diversidad de cambios que se sucedieron en el pasado. La extensión del presente produce una dilatación tal que lo convierte en la tensión temporal predominante.

Por otra parte, el peso de la culpa también explicaría la naturaleza memorial del relato, al buscar en el pasado los orígenes de esta. La idea es, como se vio, dirigirse al pasado con el afán de volver a la situación originaria y revivirla de la manera debida. Según Castilla del Pino (1989: 62), la conciencia del tiempo se muestra considerablemente en la conciencia culpable y "tras la experiencia de la culpa el sujeto adquiere conciencia de la importancia de su acción" por las cosas hasta entonces inadvertidas. Esto último coincide también con la inclusión en nuestro análisis de un enfoque kairológico del tiempo. Resulta muy interesante cómo el mismo Castilla del Pino asume este sentido del tiempo justo, del tiempo como momento decisorio. Así, afirma este popular psicólogo y pensador español:

\begin{abstract}
El hacer del hombre se ha de verificar sobre la realidad. Pero ahora estamos en condiciones de precisar más aún: la índole estructural de su estancia en determinada realidad se denomina situación. El hombre está siempre situado en su realidad, es decir, está en la realidad instalado en ella, de modo tal que en cada instante la estructura de sus relaciones se concreta en una situación. Es sobre "esta" situación sobre la que el sujeto ha de decidir (Castilla del Pino 1989: 26).
\end{abstract}

Según detalla Castilla del Pino, la responsabilidad consiste en tomar conciencia de las consecuencias de la opción que se elija en el momento de la decisión, de modo que toda decisión se vive con responsabilidad. La responsabilidad, acota además, consiste en "hacer lo que se debe hacer en esta situación en que ahora estoy" (66). Es esta conciencia del actuar y la pulsión hermenéutica, lo que diferencia a Polo de "el que escribe", por eso MP puede ser también vista como una novela de madurez y por eso también Polo y "el que escribe" están irremediablemente ligados, de la misma manera que el pasado es irremediablemente irreversible. La modificación que le acaece a "el que escribe" se da gracias a las reiteradas acciones de Polo sobre el mundo, y es el hacer de Polo el que le depara ese saber maduro sobre su hacer actual. La irreversibilidad del pasado, una vez aprehendido el sentido de su existencia, lanza el final del relato hacia el futuro, de nuevo hacia la vida que sigue y continúa como el devenir mismo del tiempo, de los seres y las cosas. La muerte es otro de los temas que se circunscriben alrededor de la culpa, pero ese será el tema del próximo artículo que publicaremos y en el que esperamos analizar otra de las novelas de Mora: Enfermedad Mortal.

\title{
Bibliografía
}

Bajtín, Mijail. 1989. Teoría y estética de la novela. Madrid: Taurus (trad. de Helena S. Kriúkova y Vicente Cazcarra). 
1994. El método formal en los estudios literarios. Introducción a una poética sociológica. Madrid: Alianza Editorial. (Trad. Tatiana Bubnova).

Cassirer, Ernest. 1976. Filosofía de las formas simbólicas. III tomo. México: Fondo de Cultura Económica.

Castilla del Pino, Carlos. 1981. La culpa. Madrid: Alianza Editorial.

Cros, Edmond. 1992. De l'engendrement des formes. Montpellier: Études Sociocritiques. Éditions du CERS. Université Paul Valéry.

Foucault, Michel. 1996. De lenguaje y literatura. Barcelona: Paidós.

Genette, Gérard. 1979. Introduction à l'architexte. París: Seuil.

Giddens, Anthony. 1998. La transformación de la intimidad. Sexualidad, amor y erotismo en las sociedades modernas. Madrid: Cátedra.

Goldmann, Lucien. 1984. Ciencias Humanas y Filosofía. Buenos Aires: Ediciones Nueva Visión.

Gómez Moriana, Antonio. 1985. La subversion du discours rituel. Quebec: Editions Le préambule.

Herra, Rafael Ángel. 1993. “Autoengaño y desculpabilización o crítica de la ética global”. Revista de Filosofía de la Universidad de Costa Rica. 31 (74): 11-6.

Kerkhoff, Manfred. 1997. Kairós. Exploraciones ocasionales en torno a tiempo y destiempo. San Juan: Universidad de Puerto Rico.

Jolles, Andrés. 1972. Las formas simples. Chile: Editorial Universitaria.

Lejeune, Philippe. 1975a. Le pacte autobiographique. París: Seuil.

1975b. Lire Leiris: Autobiographie el langage. París: Klinecksiek.

Miller, James. 1995. La pasión de Foucault. Buenos Aires: Edit. Andrés Bello.

Mora, V.A. 1979. Cachaza. San José: Editorial de la Universidad de Costa Rica.

1991. La película. San José: Editorial Universidad de Costa Rica.

1995. La distancia del último adiós. San José: Editorial Universidad de Costa Rica. 
1996. Los problemas del gato. San José: Ediciones Perro Azul.

1998. Mano a mano. San José: Editorial Icode.

Sin año. Enfermedad mortal. Texto inédito. Manuscrito proporcionado por el autor para efectos de esta investigación.

Sin año. Memorias de un psiquiatra. El final del comienzo o viceversa. Texto inédito. Manuscrito proporcionado por el autor para efectos de esta investigación.

Ricoeur, Paul. 1996. Tiempo y narración. Tiempo narrado. Vol. III. Madrid: Siglo XXI.

Todorov, Tzvetan. 1981. Mikhail Bakhtine. Le principe dialogique. Suivi de Écrits du Cercle de Bakhtine. París: Seuil.

Virilio, Paul. 1988. Estética de la desaparición. Barcelona: Anagrama. 